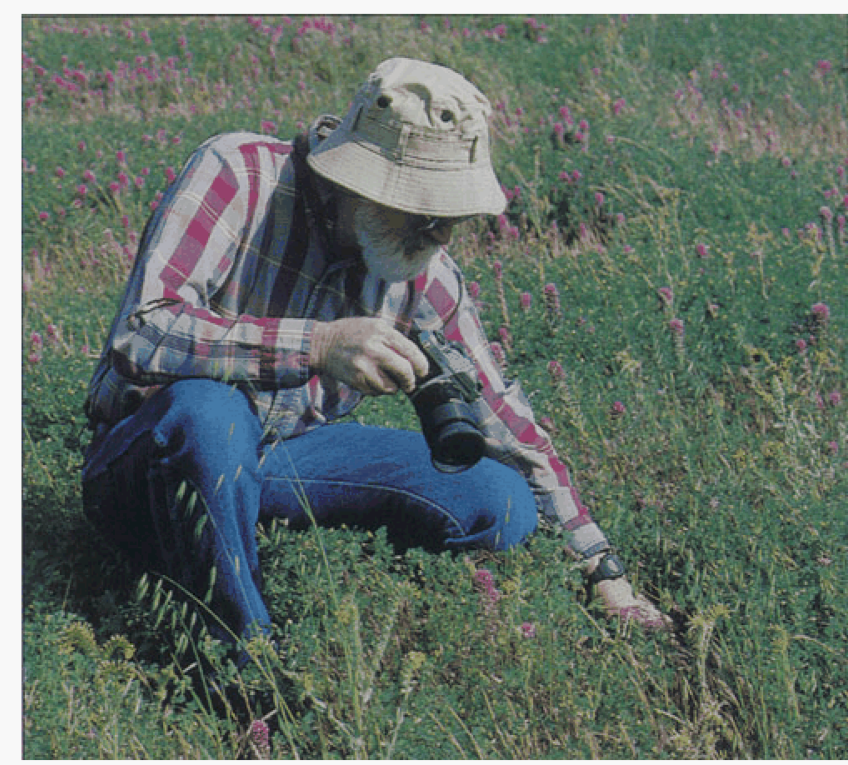

Farm advisor emeritus Walt Graves compares $7^{1 / 2}$-year-old green medic rows with short, dried-out annual grasses. Certain medics yielded more than annual grasses did.

\title{
Legumes show success on Central Coast rangeland
}

\author{
William H. Weitkamp $\square \quad$ Walter L. Graves
}

\begin{abstract}
Improvements for rangeland and ley farming systems must be economical and long-lasting if they are to be used by ranchers in lowrainfall areas of California. Commercial and research seedings of annual legumes dating back to the 1970 s and 1980s prove that certain medic varieties can be established economically and will remain productive for decades on rangelands with neutral to basic soils. In a 12-year variety trial conducted in eastern San Luis Obispo County, 13 of 18 medics survived.
\end{abstract}

The Camatta Ranch, located 25 miles east of Santa Margarita, is typical of many eastern San Luis Obispo County ranches that once had large acreages farmed to dryland barley and wheat. These crops were usually marginal and prices low. Soils became poorer with repeated tillage, and federal farm programs eventually shifted from production to conservation incentives. In the late 1980s, 100,000 acres in San Luis Obispo and southern Monterey counties were taken out of farming and enrolled in the Conservation Reserve Program (CRP).
Although only limited grazing has been allowed on CRP acreage to date, it is likely that the best use of most of the worn-out farmland now and in the future is for livestock grazing and wildlife habitat. Introducing annual legumes, which use elemental atmospheric nitrogen to make proteins (a process called nitrogen fixation), can improve quality and quantity of forage for animals. And, on land that is suitable for farming, a well-managed program of rotating the grazing of legumes by sheep or cattle with grain farming (called ley farming) can improve the soil while increasing livestock and grain production. But improvements for rangeland and ley farming systems must be economical and long-lasting if they are to be used by ranchers in low-rainfall areas of California.

\section{Camatta Trial 1}

To test the establishment, survival and production of annual legumes, 24 varieties and collections of medics and clovers were seeded on the Camatta Ranch in October 1985. Seed was inoculated using the Pelinoc method and broadcast on plots measuring 4 feet square in dryland grain stubble. We also broadcast phosphate fertilizer $(0$ -
25-0-10) on the plots at the rate of 400 pounds total material per acre. Average annual rainfall at the trial location is approximately 7 to 8 inches, and the soil is Balcom clay loam with a $\mathrm{pH}$ of 7.5 , within the desirable range for medics. Seed for 18 medics and 6 clovers was provided by author Walter Graves, who made collections in the Mediterranean region. The varieties came from Australian seed companies.

The season following the October 1985 seeding was excellent for plant germination and growth, with rains beginning in November and totaling 10 inches by the following April. Subsequently there were 4 consecutive dry years, which averaged less than 6 inches of effective rainfall. From then through 1997, annual rainfall patterns and totals varied extremely.

Plots were grazed by cattle during the spring of 1986 and the field was then entered into the CRP with no livestock grazing allowed for 10 years. At the time of the 1997 ratings referred to below, grazing had not resumed.

The plots were rated for stand and vigor ( $1=$ poor, $10=$ excellent $)$ the first spring after seeding (1986) and the twelfth spring after seeding (1997) (table 1). Data was analyzed using an analysis of variance; Duncan's multiple range was used to test for differences between means for each year.

Thirteen of 18 medics survived for 12 years, with Serena bur medic rating 9 and four others rating 7 or higher. These five best medics in 1997 were rated at least 6 in 1986, while the 10 medics that rated 5 or lower in 1986 also rated 5 or lower in 1997. So a strong start the first year appears to be desirable for long-term high regeneration and vigor in medics. But a strong start is not a guarantee of repeated dense stands and high vigor; some of the medics started with medium to high ratings and dropped off considerably by 1997 .

Serena bur and Sephi barrel medics were commercial varieties that had performed well at other locations, so their high ratings were no surprise. The other three medics that rated 7 or higher were less predictable because 
they were collections from the Mediterranean region and had no track record in this part of California. Collections of Medicago laciniata Krakra (Krakra cutleaf medic), M. laciniata 6 and M. scutellata 8121 (snail medic from Tunisia) seem to be good candidates for expansion because they had high ratings and were the only survivors in their species in 1997.

The only trifolium variety that appeared to be adapted to the trial site was Yamina cup clover, which rated 6.3 in 1997. High soil pH and low rainfall probably contributed to failure of the other trifoliums. However, commercial varieties of subterranean clovers have persisted well in other areas of the Central Coast, where annual rainfall is about 15 inches or more.

\section{Camatta Trial 2}

In an adjoining trial, 10 commercially available medic varieties were seeded and fertilized at the same time as Trial 1 (October 1985) in plots 12 feet square. Ratings made in 1986 and 1997 were analyzed using an analysis of variance; Duncan's multiple range was used to test for differences between means for each year. Serena bur and Sephi barrel persisted (table 2), but their stands were not as dense as in Trial 1. Hannaford barrel and Jemalong barrel, not included in Trial 1 , had the highest ratings in Trial 2. Circle Valley bur, also not in Trial 1, equaled Serena bur in Trial 2.

The gama medics - Sapo, Paragosa and Paraponto - persisted, although their respective ratings of 2.7, 1.7 and 0.7 were not impressive. As in Trial 1 , Robinson snail medic did not survive.

\section{Camatta drill seedings}

During the same month that Trials 1 and 2 were planted (October 1985), the ranch foreman seeded about 20 acres of a medic mix near the trial plots and in other widespread areas of

TABLE 1. Camatta Ranch Trial 1: legume varieties and collections, plot size: 4 feet $\times 4$ feet

Seeding date: Oct. 28,1985
Number of replications: 3
Seeding rate: $50 \mathrm{lb}$ per acre
Location: Camatta Ranch, east of Santa Margarita

Legume

Common or collection name (Genus and species)

Serena bur medic (Medicago hispida)

Krakra cutleaf medic (M. laciniata)

Sephi barrel medic ( $M$. truncatula)

6 cutleaf medic (M. laciniata)

17 bur medic (M. hispida)

8121 snail medic (M. scutellata - Tunisia)

Yamina cup clover (Trifolium cheleri)

604 bur medic (M. hispida)

97 bur medic (M. hispida)

$17 \mathrm{H} / \mathrm{S}$ gama medic ( $M$. rugosa)

Paraggio barrel medic (M. truncatula)

Paragosa gama medic ( $M$. rugosa)

Paraponto gama medic ( $M$. rugosa)

Sapo gama medic ( $M$. rugosa)

Beenong cup clover ( $T$. cheleri)

Sava snail medic ( $M$. scutellata)

$14 \mathrm{H} / \mathrm{S}$ Calvary medic (M. ciliaris)

135 Calvary medic (M. ciliaris)

Robinson snail medic (M. scutellata)

GR301 sub clover ( $T$. subterranean)

$11 \mathrm{H}$ snail medic ( $M$. scutellata)

400 sub clover ( $T$. subterranean)

Nungarin sub clover ( $T$. subterranean)

GR812 sub clover ( $T$. subterranean)

- Values within columns with different letters are significantly different, $P \leq .05$

$\dagger$ Varieties with 0 ratings (not present) in 1997 were omitted from statistical analysis. the ranch with a 5-foot range drill. Approximately 8 pounds of seed and 100 pounds of phosphate fertilizer (0-25-010) per acre were applied in shallow disk furrows. No additional fertilizer has been applied since this seeding. Jemalong barrel, Hannaford barrel, Paragosa gama, Serena bur and Circle Valley bur medics were in the mix.

In areas with high $\mathrm{pH}$, calcareous soils, such as the Balcom clay loam at the trial sites, barrel and bur medics have persisted throughout the 12-year period and have been very productive during average or better rainfall years. Only Paragosa gama medic has not performed well.

To illustrate the range in forage production increases due to annual medics, we clipped paired plots of 1 square foot each on May 4, 1993, in four drill-seeded locations and in four nonseeded locations immediately adjoining drill rows. Side-by-side comparisons were possible because medic plants had not spread far from the drill rows, apparently due to limitations in the spread of seed, rhizobium inoculant or both. Plots with no medics consisted mainly of annual grasses such as squirreltail fescue and red brome. This was a demonstration exercise for a field day, not a scientific experiment. Similar results should not be expected on all sites, especially where resident legumes are well established.

Rainfall was favorable for plant growth during the 1992-1993 season, as indicated by the yields on the best site $-8,256$ and 3,552 pounds dry forage per acre (table 3 ). Yet grasses on the poorest site of this sampling produced only 384 pounds, while the medics yielded 2,592 pounds, nearly 7 times more high-protein forage. Yield differences between medics and grasses ranged from 2,208 pounds for this poor site on a hilltop up to 4,800 pounds for Site 1 .

From observations made during drought years, it appeared that the percentage increase in forage production due to medics was at least as great then as in 1992-1993. The increase in pounds of forage per acre, however, was less than during the wetter year.

Perhaps more important, protein content of medic forage is higher than 


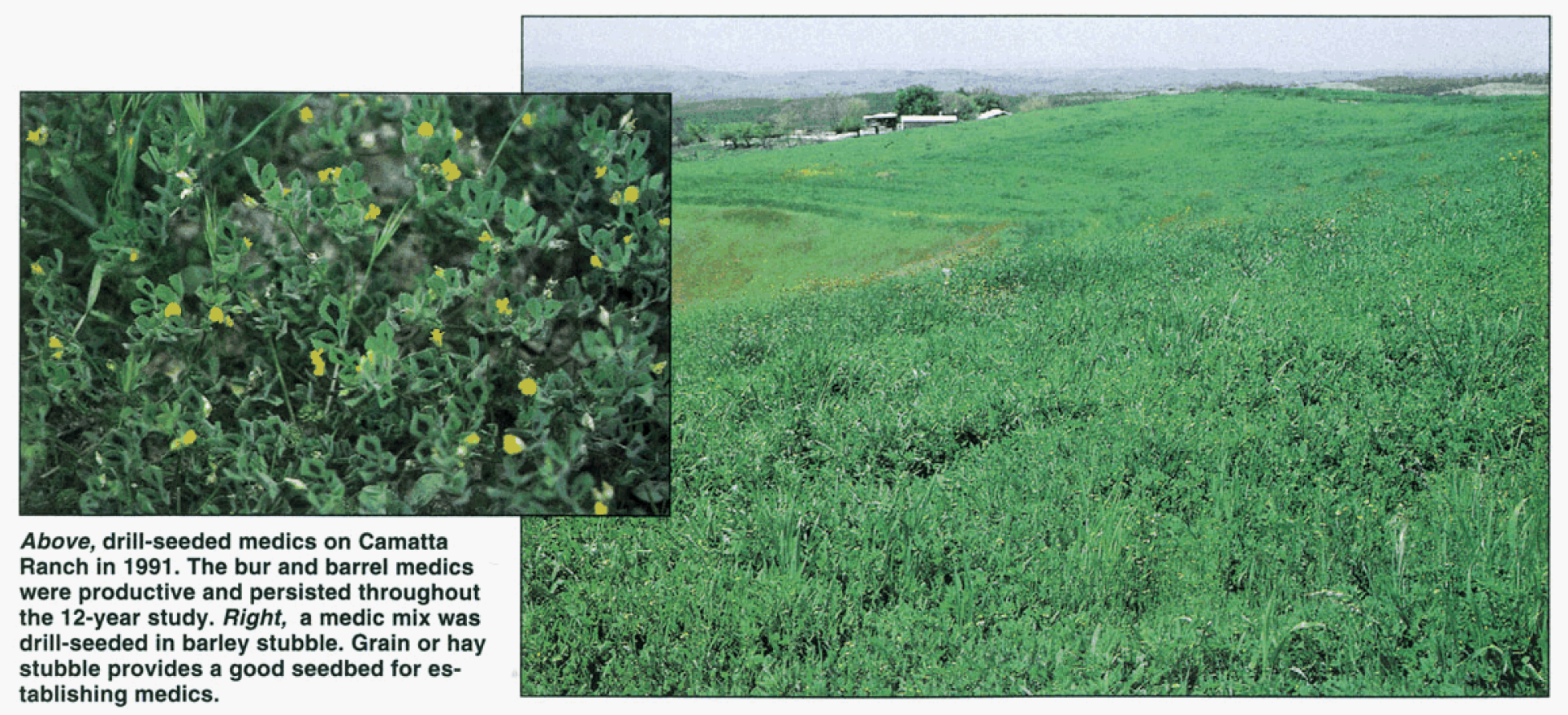

in annual grasses, especially after the grasses have headed out. In addition, medic seed pods, which are usually produced in abundance, are more palatable to livestock and provide more energy and protein than dry grasses during the summer. Local livestock managers are familiar with the nutritional value of resident annual medics such as bur clover. This benefit can be extended to many rangelands of neutral to basic $\mathrm{pH}$ in California by planting drought-tolerant medics where rainfall is too low for resident bur clovers.

Although livestock were excluded after the 1985-86 season from the CRP field where the first two trials were located, drill seedings included fields that were grazed every year. One small field included a portable corral and was heavily grazed by cattle. Medics, especially Serena bur medic, persisted as well here as in the CRP field, and the ground is covered with medic seed pods at the beginning of each summer. On many range sites, grazing is necessary for medic stands to remain productive because competing grasses and weeds will otherwise dominate due to a buildup of soil nitrogen from nitrogen fixation by the medics.

\section{Medic regeneration}

A survival characteristic of annual medics and many other annual legumes is their ability to regenerate from seed even after years of adverse weather conditions. This is due to abundant seed production and the presence of a high percentage of hard seeds, which remain dormant for 1 or more years before germinating.

An example of this survivability is a grain field near Cholame that was planted to a 6-pound mix of Jemalong barrel medic and Hykon rose clover in the fall of 1971. Because this was in a low-rainfall area with high $\mathrm{pH}$ soils, similar to the Camatta Ranch, only the medic survived and improved year by

TABLE 2. Camatta Ranch Trial 2: legume varieties and collections, plot size: 12 feet $X 12$ feet

Seeding date: Oct. 23, 1985

Number of replications: 3

Seeding rate: $20 \mathrm{lb}$ per acre

Location: Camatta Ranch, east of Santa Margarita

Fertilization: 0-25-0-10 @ $400 \mathrm{lb}$ per acre

Soil: Balcom clay loam

Soil $\mathrm{pH}: 7.5$

Inoculant: Celpril

\begin{tabular}{lcc}
\hline & \multicolumn{2}{c}{$\begin{array}{c}\text { Stand and vigor rating } \\
(1=\text { poor, 10 = excellent })\end{array}$} \\
\cline { 2 - 3 } Legume & $4 / 22 / 86$ & $3 / 31 / 97$ \\
\hline Hannaford barrel medic & $3.0 \mathrm{bc}$ & $6.3 \mathrm{a}^{*}$ \\
Jemalong barrel medic & $3.3 \mathrm{bc}$ & $5.3 \mathrm{ab}$ \\
Circle Valley bur medic & $2.7 \mathrm{~cd}$ & $5.0 \mathrm{ab}$ \\
Serena bur medic & $1.7 \mathrm{de}$ & $5.0 \mathrm{ab}$ \\
Paraggio barrel medic & $3.7 \mathrm{bc}$ & $3.3 \mathrm{abc}$ \\
Sephi barrel medic & $7.0 \mathrm{a}$ & $2.7 \mathrm{bcd}$ \\
Sapo gama medic & $1.0 \mathrm{e}$ & $2.7 \mathrm{bcd}$ \\
Paragosa gama medic & $1.0 \mathrm{e}$ & $1.7 \mathrm{~cd}$ \\
Paraponto gama medic & $1.3 \mathrm{e}$ & $0.7 \mathrm{~cd}$ \\
Robinson snail medic & $4.0 \mathrm{~b}$ & $0.0 \mathrm{~d}$ \\
\hline
\end{tabular}

-Values within columns followed by different letters are significantly different, $P \leq .05$. Duncan's multiple range was used to test for differences between means. year to a fair stand. After being grazed for several years, the field was planted to cereal grains again and then allowed to return to rangeland, with no reseeding by the 1980s.

This time the medic stand became dense and, when forage plots were clipped in April 1983 - a high-rainfall year - dry matter weighed 5,875 pounds per acre. The ley farming treatment had apparently improved the medics. In 1984, the medic seed reserve in the soil was sampled and estimated to be 500 pounds per acre; not a bad return on the few pounds per acre that were seeded in 1971. In 1997, the field is still in medics and is grazed by dairy replacement heifers.

\section{Medics survive test of time}

In areas with as little as 7 to 8 inches of rainfall per year and soils with a neutral to basic $\mathrm{pH}$, seedings of annual barrel and bur medics have survived the test of time - from 12 to

TABLE 3. Camatta Dry Matter Yield Comparisons: 1985 drill-seeded medic strips (approximately $8 \mathrm{lb}$ of medic seed and $100 \mathrm{lb}$ of $0-25-0$ 10 fertilizer per acre) versus resident annual grasses next to drill strips. Clipped in plots 1-foo square May 4, 1993, weighed after air drying.

\begin{tabular}{lcc}
\hline \hline Site & Medics & Annual grasses \\
\hline 1 & $\ldots \ldots \ldots \ldots . .$. & lb per acre $\ldots \ldots \ldots . .$. \\
2 & 5,856 & 1,056 \\
3 & 7,200 & 3,360 \\
4 & 2,592 & 384 \\
Average & $\underline{3,256}$ & 3,552 \\
\hline
\end{tabular}


26 years. Annual yields of forage and seed have varied with rainfall amount and pattern, but high-yielding stands continue to be produced during favorable years. Forage production is much higher than in surrounding unseeded areas, even though no fertilizer was applied to any of the seedings after the first year. Medics persisted with or without grazing and, in at least one case, when land was farmed to grain between years of grazing. Improvements in quality and quantity of range forage can be extended to many rangelands of California by planting drought-tolerant annual medics where rainfall is too low for resident bur clovers.

W.H. Weitkamp is Farm Advisor, UC Cooperative Extension, San Luis Obispo County, and W.L. Graves is Farm Advisor, Emeritus, UCCE, San Bernardino County.

\section{Further reading}

George MR, Adams TE, Clawson WJ. 1983. Seeded Range Plants of California. University of California Cooperative Extension Leaflet 21344. $23 \mathrm{p}$

Phillips DA, Williams WA. 1987. Rangelegume Inoculation and Nitrogen Fixation by Root-nodule Bacteria. University of California Agricultural Experiments Station Bulletin 1842. $13 \mathrm{p}$.

Weitkamp B. 1993. Planting and Managing Range Legumes and Grasses in San Luis Obispo County. San Luis Obispo, California: University of California Cooperative Extension Range Management Fact Sheet. $4 \mathrm{p}$.

Weitkamp B, Graves W. 1987. Annual medics for range and grain lands. Range Science Report No. 9. Department of Agronomy and Range Science, University of California, Davis, California. $6 \mathrm{p}$

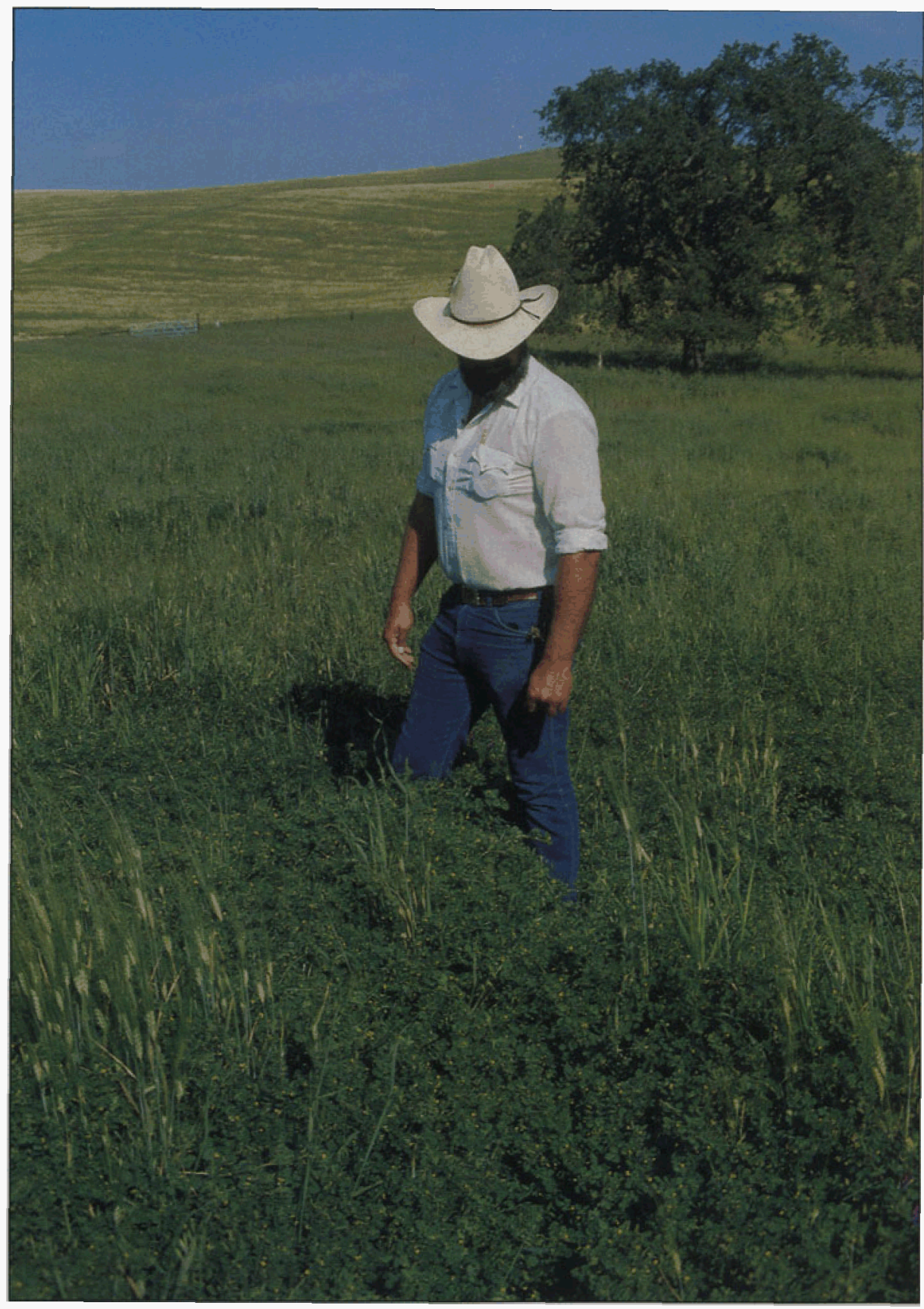

Farm advisor Michael Smith examines a field of Circle Valley bur, Jemalong barrel and Paragosa gama medics seeded in barley stubble. Annual medics are able to regenerate from seed even after years of adverse weather.

\section{CALIFORNIA AGRICULTURE ASSOCIATE EDITORS}

\section{Animal, Avian, Aquaculture}

\section{\& Veterinary Sciences}

Christopher M. Dewees

Kathryn Radke

Bennie I. Osburn

Barbara A. Reed

Economics \& Public Policy

Richard A. Howitt

Alvin Sokolow

\section{Food \& Nutrition}

Barbara Schneeman

Eunice Williamson
Human \& Community

\section{Development}

Linda M. Manton

Karen P. Varcoe

\section{Land, Air \& Water Sciences}

Garrison Sposito

Henry J. Vaux, Jr.

Natural Resources

Barbara H. Allen-Diaz

Daniel W. Anderson

Richard B. Standiford http://danr.ucop.edu/calag/

CALAG@ucop.edu

PH: 510 987-0044

FAX: $510465-2659$
Edward G. Platzer

Joseph G. Hancock, Jr. Michael K. Rust

Plant Sciences

Jodie S. Holt

Lee F. Jackson

G. Steven Sibbett 